\title{
Effect of Different Seed Rhizome Weight and Nutrition Levels on Yield, Quality and Economics of Mango Ginger (Curcuma amada Roxb.) Cultivation
}

\author{
B.M. Priyanka ${ }^{1 *}$, H.R. Bhoomika ${ }^{1}$, H.S. Sannidi ${ }^{1}$, M. Shivaprasad ${ }^{3}$, \\ L. Hanumanthraya ${ }^{4}$ and Sadashiv Nadukeri ${ }^{1}$
}

${ }^{1}$ Department of Plantation, Spice, Medicinal and Aromatic Crops, ${ }^{2}$ Department of Agronomy,

${ }^{3}$ Department of Entomology, College of Horticulture, Mudigere-577132, Chikkamagaluru, Karnataka, India

*Corresponding author

\begin{tabular}{|c|c|}
\hline & A B S T R A C T \\
\hline Keywords & \multirow{4}{*}{$\begin{array}{l}\text { Mango ginger (Curcuma amada Roxb.) is popular in Southern and Eastern India mainly } \\
\text { due to its typical pleasant flavor. It is a spice cum medicinal plant that has been reported to } \\
\text { possess anti-inflammatory, antioxidant and antitumor properties. The rhizomes find an } \\
\text { extensive application in the preparation pickles because of its exotic mango aroma. A field } \\
\text { experiment was conducted at College of Horticulture, Mudigere to standardize the } \\
\text { nutrition levels and seed rhizome weight for getting higher yields. The treatments } \\
\text { consisted of two factors viz., rhizome weight }\left(\mathrm{W}_{1}-20, \mathrm{~W}_{2}-40, \mathrm{~W}_{3}-60 \mathrm{~g}\right) \text { and nutrition levels } \\
\left(\mathrm{N}_{1}-\mathrm{Control}, \mathrm{N}_{2}-60: 50: 100 \mathrm{~kg} \mathrm{NPK} / \mathrm{ha}, \mathrm{N}_{3}-90: 75: 150 \mathrm{~kg} \mathrm{NPK} / \mathrm{ha}, \mathrm{N}_{4}-120: 100: 200 \mathrm{~kg}\right. \\
\left.\mathrm{NPK} / \mathrm{ha}, \mathrm{N}_{5}-150: 125: 250 \mathrm{~kg} \mathrm{NPK} / \mathrm{ha}, \mathrm{N}_{6}-180: 150: 300 \mathrm{~kg} \mathrm{NPK} / \mathrm{ha}\right) \text {. Among } 18 \text { treatment } \\
\left.\text { combinations, } \mathrm{W}_{3} \mathrm{~N}_{6} \text { (rhizomes weighing } 60 \mathrm{~g} \text { with } 180: 150: 300 \mathrm{~kg} \mathrm{NPK} / \mathrm{ha}\right) \text { recorded } \\
\text { maximum yield per hectare, essential oil content and it was observed that maximum B:C } \\
\text { ratio was recorded in the treatment combination } \mathrm{W}_{1} \mathrm{~N}_{6}(2.11) \text { followed by } \mathrm{W}_{3} \mathrm{~N}_{6}(2.05) \text {. }\end{array}$} \\
\hline $\begin{array}{l}\text { Mango ginger, } \\
\text { Rhizome, Yield, } \\
\text { Nutrition, Essential } \\
\text { oil, Economy }\end{array}$ & \\
\hline Article Info & \\
\hline $\begin{array}{l}\text { Accepted: } \\
\text { 08 July } 2018 \\
\text { Available Online: } \\
10 \text { August } 2018\end{array}$ & \\
\hline
\end{tabular}

\section{Introduction}

Mango-ginger (Curcuma amada Roxb., Zingiberaceae) is a perennial herb cultivated as an annual with rhizomes having characteristic odour of raw mangoes. The rhizome finds extensive use in the indigenous systems of medicine. The quality of mangoginger is mainly determined by its volatile oil, non-volatile ether extract (NVEE), fibre and starch contents.
They also reported to have antimicrobial, antioxidant, anticancer, anti-inflammatory, antidepressant, antitubercular and platelet aggregation inhibitory activities (Policegoudra et al., 2010).

The geographical distribution of the genus ranges from India to Thailand, Indo-China, Malaysia, Indonesia and Northern Australia. It is found wild in parts of West Bengal and is cultivated in Gujarat, Uttar Pradesh, Kerala, 
Karnataka, Tamil Nadu and the North-Eastern states. Nitrogen, Phosphorus and Potassium are considered as the three major nutrient elements which influence the growth and yield of crops. However, plants get some amount of nutrition from the soil, but an external supply of these nutrients in the form of fertilizer is necessary. In crops where the propagules are the economic part, it is necessary to consider the seed rate and standardize it which is economically feasible to the grower. Considering these facts, the present investigation was undertaken to standardize the major nutrient requirements and seed rhizome weight of mango ginger for commercial cultivation.

\section{Material and Methods}

The experiment was laid out in Factorial Randomized Complete Block Design in existing arecanut plantation as an intercrop at College of Horticulture, Mudigere. The treatments were replicated thrice. The raised beds of $3 \mathrm{~m} \mathrm{X} 1 \mathrm{~m}$ size were prepared in between existing 10 years old arecanut palms spaced at $2.7 \mathrm{~m} \mathrm{X} 2.7 \mathrm{~m}$ in hexagonal system. A space of $45 \mathrm{~cm}$ was left between adjacent plots. The spacing followed was $30 \mathrm{~cm}$ between rows and $30 \mathrm{~cm}$ between plants. There were totally 30 plants in each plot. The plots were kept weed-free by hand weeding at an interval of 40-50 days. The plots were irrigated at an interval of 2-3 days in initial growth period. Later the irrigation interval increased to once in a week depending on the soil moisture conditions. Earthing up was done to keep the plant base covered. Totally four weedings, two earthing up and four irrigations were taken up during the entire crop growth period.

The yield of rhizomes per hectare was worked out by weight of rhizomes obtained from each net plot and expressed in tonnes per hectare. Essential oil content on the fresh weight basis was obtained by steam distillation of freshly harvested rhizome using Clevenger apparatus (AOAC, 1975). B:C ratio was obtained by dividing gross returns with total cost of cultivation.

The data obtained were statistically analyzed as per the procedure and design given by Panse and Sukhatme (1985). The statistical significance was tested by applying ' $F$ ' test at 0.05 level of probability and critical differences were calculated for those parameters which turned significant $(\mathrm{P}<$ 0.05) to compare the effects of different treatments.

\section{Results and Discussion}

The effect of major nutrients and seed rhizome weight on yield and essential oil content of mango ginger is presented in Table 1. Maximum yield per hectare $(31.47 \mathrm{t} / \mathrm{ha})$ and essential oil content (0.73) were recorded at higher NPK level 180:150:300 kg/ha $\left(\mathrm{N}_{6}\right)$. The yield per hectare increased from 16.32 $\mathrm{t} / \mathrm{ha}$ to $31.47 \mathrm{t} / \mathrm{ha}$ with the increase in nutrient levels from no application of fertilizers to 180:150:300 kg NPK/ha. So, increasing trend in yield per hectare, was observed with increase in nutrient levels. This might be due to nitrogen being the constituents of chlorophyll, protein and plant cell, promotes vegetative growth and increased the photosynthesis process of the plants. Similarly phosphorus and potassium also promote crop growth by activating a number of enzyme system involved in photosynthesis, carbohydrate metabolism and protein synthesis. Which is ultimately synthesizes more food material for increasing yield attributes. The results are in close conformity with the findings of Dayankatti and Sulikeri (2000), Medda and Hore (2003), Haque et al., (2007), Hikaru et al., (2007), Karthikeyan et al., (2009), Tripathi and Singh (2010) and Reddy et al., (2015) (Table 2). 
Table.1

\begin{tabular}{|c|c|c|c|c|c|c|c|c|c|c|c|c|c|c|}
\hline \multirow[b]{2}{*}{ Treatment } & \multicolumn{7}{|c|}{ Yield per hectare (t/ha) } & \multicolumn{7}{|c|}{ Essential oil content (\%) } \\
\hline & N1 & $\mathbf{N} 2$ & N3 & N4 & N5 & N6 & Mean & N1 & $\mathbf{N} 2$ & N3 & N4 & N5 & N6 & Mean \\
\hline W1 & 15.27 & 17.93 & 18.94 & 25.21 & 26.07 & 28.43 & 21.97 & 0.53 & 0.57 & 0.55 & 0.67 & 0.69 & 0.71 & 0.62 \\
\hline W2 & 16.76 & 20.85 & 21.51 & 29.25 & 29.64 & 30.13 & 24.69 & 0.54 & 0.59 & 0.63 & 0.68 & 0.70 & 0.72 & 0.64 \\
\hline W3 & 16.93 & 23.82 & 26.07 & 31.79 & 33.33 & 35.86 & 27.96 & 0.65 & 0.64 & 0.73 & 0.74 & 0.75 & 0.78 & 0.71 \\
\hline \multirow[t]{2}{*}{ Mean } & 16.32 & 20.87 & 22.17 & 28.75 & 29.68 & 31.47 & & 0.57 & 0.60 & 0.63 & 0.69 & 0.71 & 0.73 & \\
\hline & \multicolumn{4}{|c|}{ SEm \pm} & \multicolumn{3}{|c|}{ CD $(5 \%)$} & \multicolumn{4}{|c|}{ SEm \pm} & \multicolumn{3}{|c|}{ CD (5\%) } \\
\hline W & \multicolumn{4}{|c|}{0.30} & \multicolumn{3}{|c|}{0.88} & \multicolumn{4}{|c|}{0.01} & \multicolumn{3}{|c|}{ NS } \\
\hline $\mathrm{N}$ & \multicolumn{4}{|c|}{0.43} & \multicolumn{3}{|c|}{1.24} & \multicolumn{4}{|c|}{0.02} & \multicolumn{3}{|c|}{0.05} \\
\hline $\mathrm{W} \times \mathrm{N}$ & \multicolumn{4}{|c|}{0.75} & \multicolumn{3}{|c|}{2.16} & \multicolumn{4}{|c|}{0.03} & \multicolumn{3}{|c|}{ NS } \\
\hline $\begin{array}{l}\text { Fac } \\
\mathrm{W}_{1-} \\
\mathrm{W}_{2-} \\
\mathrm{W}_{3-}\end{array}$ & $\begin{array}{l}\text { 1:Rhiz } \\
\text { izomes } \\
\text { nizomes } \\
\text { aizomes }\end{array}$ & $\begin{array}{l}\text { e weight } \\
\text { ghing } 20 \\
\text { ighing } 4 \\
\text { ighing } 6\end{array}$ & & $\begin{array}{l}\text { tor 2:Nut } \\
\text { Control } \\
60: 50: 10 \\
90: 75: 15\end{array}$ & $\begin{array}{l}\text { NPK/ha } \\
\text { NPK/ha }\end{array}$ & $\begin{array}{l}\mathrm{N}_{4}-120: \\
\mathrm{N}_{5}-150: 1 \\
\mathrm{~N}_{6}-180: 1\end{array}$ & $\begin{array}{l}0: 200 \mathrm{~kg} \\
: 250 \mathrm{~kg} \mathrm{~N} \\
: 300 \mathrm{~kg} \mathrm{~N}\end{array}$ & $\begin{array}{l}\text { K/ha } \\
\text { K/ha } \\
\text { K/ha }\end{array}$ & & & & & & \\
\hline
\end{tabular}


Table.2 Effect of seed rhizome weight and nutrition levels on economics of mango ginger (Curcuma amadaRoxb.) per hectare

\begin{tabular}{|c|c|c|c|c|}
\hline Treatments & $\begin{array}{c}\text { Total cost of } \\
\text { cultivation }(\mathrm{Rs})\end{array}$ & $\begin{array}{l}\text { Gross returns } \\
\text { (Rs) }\end{array}$ & $\begin{array}{l}\text { Net returns } \\
\quad(\mathrm{Rs})\end{array}$ & $\mathrm{B}: \mathrm{C}$ ratio \\
\hline $\mathrm{W}_{1} \mathrm{~N}_{1}$ & 236000 & 274860 & 38860 & 1.16 \\
\hline $\mathrm{W}_{1} \mathrm{~N}_{2}$ & 237908 & 322740 & 84832 & 1.35 \\
\hline $\mathrm{W}_{1} \mathrm{~N}_{3}$ & 238862 & 340920 & 102058 & 1.42 \\
\hline $\mathrm{W}_{1} \mathrm{~N}_{4}$ & 239816 & 453780 & 213964 & 1.89 \\
\hline $\mathrm{W}_{1} \mathrm{~N}_{5}$ & 240770 & 469260 & 228490 & 1.94 \\
\hline $\mathrm{W}_{1} \mathrm{~N}_{6}$ & 241723 & 511740 & 270017 & 2.11 \\
\hline $\mathrm{W}_{2} \mathrm{~N}_{1}$ & 272000 & 301680 & 29680 & 1.10 \\
\hline $\mathrm{W}_{2} \mathrm{~N}_{2}$ & 273908 & 375300 & 101392 & 1.37 \\
\hline $\mathrm{W}_{2} \mathrm{~N}_{3}$ & 274862 & 387180 & 112318 & 1.40 \\
\hline $\mathrm{W}_{2} \mathrm{~N}_{4}$ & 275816 & 526500 & 250684 & 1.90 \\
\hline $\mathrm{W}_{2} \mathrm{~N}_{5}$ & 276770 & 533520 & 256750 & 1.92 \\
\hline $\mathrm{W}_{2} \mathrm{~N}_{6}$ & 277723 & 542340 & 264617 & 1.95 \\
\hline $\mathrm{W}_{3} \mathrm{~N}_{1}$ & 308000 & 304740 & -3260 & 0.98 \\
\hline $\mathrm{W}_{3} \mathrm{~N}_{2}$ & 309908 & 428760 & 118852 & 1.38 \\
\hline $\mathrm{W}_{3} \mathrm{~N}_{3}$ & 310862 & 469260 & 158398 & 1.50 \\
\hline $\mathrm{W}_{3} \mathrm{~N}_{4}$ & 311816 & 572220 & 260404 & 1.83 \\
\hline $\mathrm{W}_{3} \mathrm{~N}_{5}$ & 312770 & 599940 & 287170 & 1.91 \\
\hline $\mathrm{W}_{3} \mathrm{~N}_{6}$ & 313723 & 645480 & 331757 & 2.05 \\
\hline
\end{tabular}


The plants raised from the bigger seed rhizome $(60 \mathrm{~g})$ produced higher yield (27.96 t/ha). The yield increased with increase in weight of the rhizome this might be due to increased accumulation of carbohydrates, proteins and starch in the heavier rhizomes which in turn is a result of better aerial growth or better translocation of assimilates from source to sink. The results are in close conformity with the findings of Girma and Kindie (2008), Monnaf et al., (2010) and Sengupta and Dasgupta (2011) in ginger and Dhatta et al., (2008) in turmeric. Interaction effect of rhizome size and major nutrients was found to be significant. Among the treatments, the combination of $60 \mathrm{~g}$ rhizome size and NPK levels at 180:150:300 kg $\mathrm{NPK} /$ ha $\left(\mathrm{W}_{3} \mathrm{~N}_{6}\right)$ recorded highest values for yield per hectare.

A gradual increase in essential oil content was recorded with increase in the fertilizer dose. Fertilizer dose of 180:150:300 kg NPK/ha $\left(\mathrm{N}_{6}\right)$ recorded maximum essential oil content $(0.73 \%)$ whereas, the minimum essential oil of $(0.57 \%)$ was recorded in control $\left(\mathrm{N}_{1}\right)$ This might be due to potassium is known to influence quality of the rhizomes such as curcumin, oleoresin and essential oil content. Hence, the application of the higher dose of potassium enhanced the essential oil content of the rhizomes. Similar, results were noticed by Dayankatti and Sulikeri (2000) in ginger, Medda and Hore (2003), Akamine et al., (2007), Hikaru et al., (2007) and Rakesh and Singh (2010) in turmeric. The essential oil content did not found to vary significantly with varied rhizome weight. However, larger seed rhizomes of $60 \mathrm{~g}$ recorded higher oil content and interaction effect on seed rhizome weight and nutrition levels on essential oil content also did not differ significantly.

Economics of mango ginger was also influenced by different seed rhizome weight and nutrition. The maximum gross returns (Rs
6,45,480) and net returns (Rs. 3,31,757) were recorded in treatment combination $\mathrm{W}_{3} \mathrm{~N}_{6}$. B:C ratio (2.11) was maximum in treatment combination $\mathrm{W}_{1} \mathrm{~N}_{6}$ followed by $\mathrm{W}_{3} \mathrm{~N}_{6}$ (2.05). Higher B:C ratio in $\mathrm{W}_{1} \mathrm{~N}_{6}$ can be justified by better rhizome yield, less incidence of pest and diseases and less investment on planting material which altogether maximized net income and in turn higher profit.

In conclusion, the experimental results revealed that the seed rhizomes weighing $60 \mathrm{~g}$ with plant nutrition at 180:150:300 kg NPK/ha has significantly increased the plant growth and rhizome yield in mango ginger. Further research on aspects like INM and micronutrients are proposed in mango ginger.

\section{References}

Akamine, H., Hossain, M. A., Ishimine, Y., Yogi, K., Hokama, K., Iraha, Y. and Aniya, Y., 2007, Effects of Application of N, P and K Alone or in Combination on Growth, Yield and Curcumin Content of Turmeric (Curcuma longa L.). Plant Prod. Sci., 10(1): 151-154.

AOAC, 1975, Association of official analytical Chemists, XII Ed. Washington, USA.

Dayankatti, B. S. and Sulikeri, G. S., 2000, Effect of plant population and nitrogen levels on growth, yield and quality of ginger - growth attributes. Kar. J. Agri. Sci., 13(4): 1047-1048.

Dhatta, A.S., Sidhu and Naveen GARG., 2008, Effect of planting material on plant growth, yield and rhizome size of turmeric. Indian. J. Hort., 65(2): 193-195.

Girma, H. and Kindie, T., 2008, The effects of seed rhizome size on the growth, yield and economic return of ginger (Zingiber officinale Rosc.). Asian. J. Pl. Sci., 7(2): 213-17. 
Haque, M. M., Rahman A.K.M.M., Ahmed, M., Masud, M. M. and SARKER, M.M.R., 2007, Effect of nitrogen and potassium on the yield and quality of turmeric in hill slope. Int. J. Sustain. Crop Prod., 2(6): 10-14.

Hikaru, A., Hossain, A., Ishimine, Y., Yogi, K., Hokama, Y., Iraha, Y. and Yoko, A., 2007, Effects of application of $\mathrm{N}$, $\mathrm{P}$ and $\mathrm{K}$ alone or in combination on growth, yield and curcumin content of turmeric (Curcuma longa L.). Pl. Production Sci., 10(1): 151-154.

Karthikeyan, P. K., Ravichandran, M., Imas, P. and Assaraf, M., 2009, The effect of potassium on the yield and quality of turmeric (Curcuma longa). Int. Potash Institute, Horgen, Switzerland. No. 21.

Medda, P. S. and Hore, J. K., 2003, Effect of $\mathrm{N}$ and $\mathrm{K}$ on the growth and yield of turmeric in alluvial plains of West Bengal. Ind. J. Hort., 60(1): 84-88.

Monnaf, M. A., Rahim, M. A., Hossain, M. A., ALAM, M. S., 2010, Effect of planting method and rhizome size on the growth and yield of ginger. $J$. Agroforestry Environ Sci., 4(2): 73-76.

Panse, V. G. and Sukhatme, P.V., 1985, Statistical Methods for Agriculture Workers., 14- 33.

Policegoudra, R. S., Rehna, K.., Rao. L. J. and Aradhya, S. M., 2010, Antimicrobial, antioxidant, cytotoxicity and platelet aggregation inhibitory activity of a novel molecule isolated and characterized from mango ginger (Curcuma amada Roxb.) rhizome. $J$ Bio sci., 35: 231-240.

Rakesh, B. and Singh, A. K., 2010, Effect of phosphorus levels on growth and yield of turmeric (Curcuma longa L.). J. Spices and Aromatic Crops., 19 (1 \& 2): 76-78.

Reddy D. V. R., Maruthi, S. G. R., Subbaiah KR, Sreenivasa, C. M., Sharma, S. H. K., Pushpanjali, N., Visha, K. V. and Sravani, P. N., 2015, Soil-PlantFertilizer relationships in turmeric assessment of Soil-Plant-FertilizerNutrient relationships for sustainable productivity of turmeric under Alfisols and Inceptisols in Southern India. Communications in Soil Science and Plant Analysis., 46: 781-99.

Sengupta, D. K., Dasgupta, B., 2011, Effect of the weight of planting material on growth and yield of ginger (Zinger officinale Rosc.) in the hilly region of Darjeeling district. Envir. Ecol., 29(2): 666-669.

Tripathi, S. and Singh, D. K., 2010, Effects of dates of planting, fertility levels and varieties on growth and yield of turmeric. Int. J. Pl. Sci., 5(1): 266-268.

\section{How to cite this article:}

Priyanka, B.M., H.R. Bhoomika, H.S. Sannidi, M. Shivaprasad, L. Hanumanthraya and Sadashiv Nadukeri. 2018. Effect of Different Seed Rhizome Weight and Nutrition Levels on Yield, Quality and Economics of Mango Ginger (Curcuma amada Roxb.) Cultivation. Int.J.Curr.Microbiol.App.Sci. 7(08): 1213-1218. doi: https://doi.org/10.20546/ijcmas.2018.708.136 